\title{
Refractory Seizure in a Patient With Griscelli Syndrome: A Unique Case With One Mutation and a Novel Deletion
}

Juan Fernando Ortiz ${ }^{1,2}$, Samir Ruxmohan ${ }^{3}$, Ivan Mateo Alzamora ${ }^{4}$, Amrapali Patel ${ }^{5}$, Ahmed EissaGarcés ${ }^{1}$

1. Neurology, Universidad San Francisco de Quito, Quito, ECU 2. Neurology, Larkin Community Hospital, Miami, USA 3. Neurology, Larkin Community Hospital, Miami, Florida, USA 4. Medicine, Universidad San Francisco de Quito, Quito, ECU 5. Public Health, George Washington University, Washington, USA

Corresponding author: Juan Fernando Ortiz, sumjuanfer41@gmail.com

\section{Abstract}

Griscelli syndrome (GS) is a rare syndrome characterized by hypopigmentation, immunodeficiency, and neurological features. The genes Ras-related protein (RAB27A) and Myosin-Va (MYO5A) are involved in this condition's pathogenesis.

We present a GS type 1 (GS1) case with developmental delay, hypotonia, and refractory seizures despite multiple medications, which included clobazam, cannabinol, zonisamide, and a ketogenic diet. Lacosamide and levetiracetam were added to the treatment regimen, which decreased the seizures' frequency from 10 per day to five per day. The patient had an MYO5A mutation and, remarkably, a deletion on 18p11.32p11.31. The deletion was previously reported in a patient with refractory seizures and developmental delay. We reviewed all cases of GS that presented with seizures. We reviewed other cases of GS and seizures described in the literature and explored possible seizure mechanisms in GS. Seizure in GS1 seems to be related directly to the MYO5A mutation.

The neurological manifestations in GS2 seem to be caused indirectly by the accelerated phase of Hemophagocytic syndrome (HPS), which is characteristic of GS2. By having the MYO5A gene mutation combined with the 18p11.32p11.31 deletion, the prognosis and severity of the patient's condition are poor. This is the first report of GS1 with a deletion in 18p11.32p11.31.

Review began 04/05/2021 Review ended 04/07/2021 Published 04/10/2021

() Copyright 2021 Ortiz et al. This is an open access article distributed under the terms of the Creative Commons Attribution License CC-BY 4.0., which permits unrestricted use, distribution, and reproduction in any medium, provided the original author and source are credited.
Categories: Neurology

Keywords: griscelli syndrome, seizures

\section{Introduction}

Griscelli syndrome (GS) is an autosomal recessive disorder characterized by hypopigmentation, immunodeficiency, and neurological features [1]. The syndrome was first described in 1978 [2]. Only 150 cases have been reported to date, with a higher prevalence in Mediterranean countries such as Turkey [2-3]. GS usually manifests from four months to four years, but other studies have reported a range from one month to eight years [2].

Two genes on chromosome 15q21, Ras-related protein Rab-27A (RAB27A) and Myosin-Va (MYO5A), are the cause of GS [1]. GS type 1 (GS1) presents with partial albinism and neurological features while GS type 2 (GS2) presents with partial albinism and immunodeficiency [4]. GS type 3 (GS3) is caused by a mutation in chromosome 2q37.1, which encodes melanophilin; the disease is usually benign [1]. RAB27A has an immunologic effect. The gene is expressed in cytotoxic T cells and natural killer cells [4]. The gene regulates the docking of proteins and exocytosis of granules containing granzyme and perforins. The dysfunction in cytotoxic T cells and natural killer cells explains the immunodeficiency seen in GS2. The gene MYO5A regulates the organelle transport in melanocytes and neuronal cells [5].

GS is an extremely rare disorder. Knowing the peculiarities of the clinical presentations is difficult because there is not sufficient information. We present a case of GS1 with an additional deletion (18p11.32p11.31). This deletion was previously reported by Verroti et al. [6]. This patient presented with similar clinical features as our patient, including drug-resistant atypical absence epilepsy and severe developmental delay [6]. The main concern of the patient was refractory seizures. We have presented the differential diagnosis of the disorder, differentiated each type of GS, and reviewed cases of GS with seizures. Finally, we have discussed the possible causes of seizures and the prognosis in each type of GS.

\section{Case Presentation \\ History of present illness}




\section{Cureus}

A three-year-old male was brought to the hospital by his mother due to increased seizure frequency despite being on multiple anti-seizure medications. The patient was admitted for further assessment. Past medical history was relevant for epilepsy, infantile spasms, developmental delay, gastroesophageal reflux, laryngomalacia, and dysphagia. The mother denied any prenatal or neonatal complications. A genetic test showed a mutation in the MYO5A gene of chromosome 15q21, suggesting GS.

\section{Seizure history}

The child was diagnosed with infantile spasms at 11 months of age, and he was successfully treated with prednisone. He was started on clobazam for seizure prophylaxis, but he developed myoclonic seizures after two months. Clobazam dose was adjusted, which helped reduce the frequency of the seizures.

At 16 months of age, he started having tonic-clonic seizures and was started on a ketogenic diet, which decreased the seizures' frequency from 20 episodes to 10 episodes a day. He was also given cannabinol at age two, which decreased the seizures' frequency to less than five per day. However, seizures recurred again with frequencies above 10 per day.

At two years and three months, he was started on levetiracetam without any significant change. Three months later, zonisamide was given without any significant effects. The child's neurologist felt that the ketogenic diet was no longer helpful, and, therefore, the patient was weaned off the diet. The dose of zonisamide was increased, which reduced the seizures' frequency to four to five episodes a day.

\section{Physical exam}

Table 1 shows the results of the physical exam of the patient.

\begin{tabular}{|c|c|c|c|}
\hline \multicolumn{4}{|l|}{ Physical Exam } \\
\hline Weight & 13.1 kg & HEENT & $\begin{array}{l}\text { Hypopigmented eyebrows, eyebrows, light } \\
\text { blonde hair, and a small nose }\end{array}$ \\
\hline Cardiopulmonary & $\begin{array}{l}\text { No extremity edema, murmurs, or pathological } \\
\text { pulmonary sounds. }\end{array}$ & $\begin{array}{l}\text { Gastrointestinal- } \\
\text { renal }\end{array}$ & No abnormalities \\
\hline Skin & $\begin{array}{l}\text { No visible or palpable lesions. There are no } \\
\text { cutaneous stigmata of neurological disease. }\end{array}$ & Psychiatric & Global delay \\
\hline \multicolumn{4}{|l|}{ Neurological Exam } \\
\hline Cranial nerves & $\begin{array}{l}\text { Intermittent disconjugate eye movements, face } \\
\text { symmetric, maintains head when turned to the } \\
\text { right }\end{array}$ & Motor & $\begin{array}{l}\text { Generalized axial and appendicular } \\
\text { hypotonia, the head is lagging. No tremors or } \\
\text { dyskinesia seen; the muscle bulk is } \\
\text { decreased }\end{array}$ \\
\hline Sensory & Normal sensation & $\begin{array}{l}\text { Gait and } \\
\text { Reflexes }\end{array}$ & $\begin{array}{l}\text { Unable to maintain sitting position, marked } \\
\text { head lag, } 2+\text { biceps, } 1+\text { patella bilaterally. No } \\
\text { clonus. Toes going down. }\end{array}$ \\
\hline \multicolumn{4}{|c|}{ Developmental History } \\
\hline Gross motor & $\begin{array}{l}\text { It was delayed prior to spasms at age } 11 \\
\text { months, he can roll over, he has difficulty in } \\
\text { maintaining a sitting position }\end{array}$ & Speech & Babbles, no words. \\
\hline Social & $\begin{array}{l}\text { Does not interact with siblings. No separation } \\
\text { anxiety. Cries when he wants something. }\end{array}$ & Fine motor & Pincer grasp \\
\hline
\end{tabular}

\section{TABLE 1: Physical exam of the patient}

HEENT: head, eyes, ears, nose, and throat; Kg: kilograms

\section{Diagnostic assessment}

Laboratory

White blood cell (WBC) count was $5.8 \times 109 / \mathrm{L}$, hemoglobin (Hb) $13.1 \mathrm{~g} / \mathrm{dl}$, hematocrit (HCT) $36.2 \%$, platelet (PLT) $161 \times 109 / \mathrm{L}, \mathrm{Na} 137 \mathrm{mEq} / \mathrm{L}, \mathrm{K} 4.5 \mathrm{mEq} / \mathrm{L}, \mathrm{CO}_{2} 20.0 \mathrm{mEq} / \mathrm{L}, \mathrm{Cl} 101 \mathrm{mEq} / \mathrm{L}, \mathrm{Cr} 0.18 \mathrm{mg} / \mathrm{dL}$, and blood urea 


\section{Cureus}

nirogen (BUN) $4 \mathrm{mg} / \mathrm{dL}$.

Magnetic Resonance Imaging (MRI)

There was poor differentiation of the gray-white matter interface in the temporal and frontal lobes, with atrophy in the frontal lobe and infratentorial region. Secondary ex-vacuo ventriculomegaly was also seen. Figure 1 shows the MRI findings in this patient.

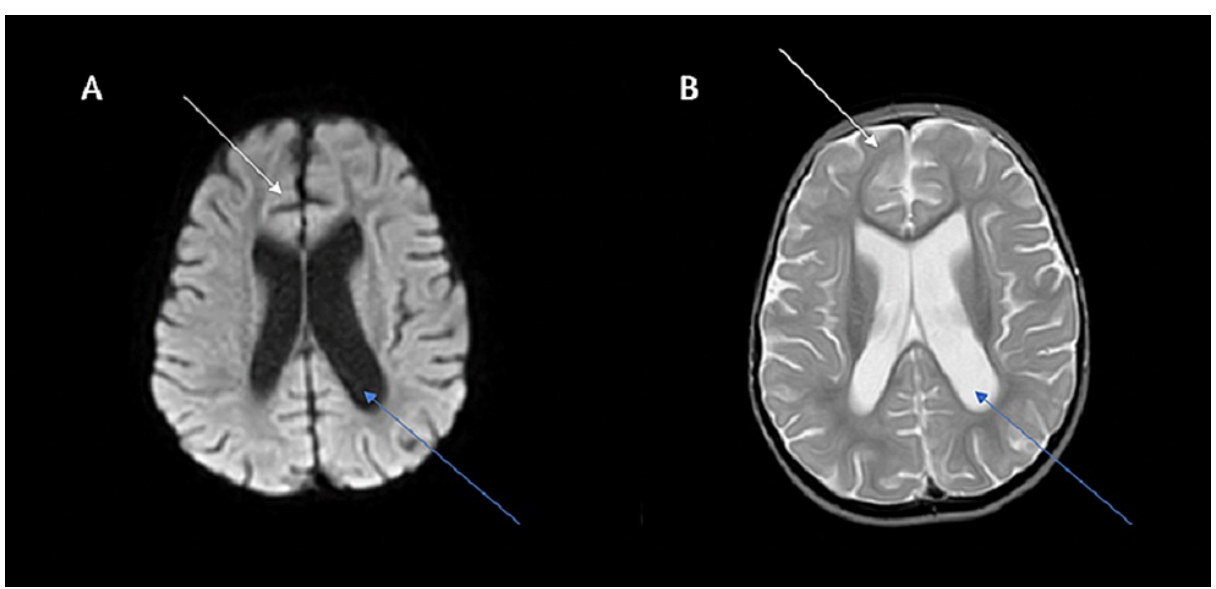

FIGURE 1: Image A: T1 MRI sequence, axial view Image B: T2 MRI sequence, axial view: both images show ex vacuo ventriculomegaly (blue arrows) and frontal atrophy (white arrows).

MRI: magnetic resonance imaging

Figure 2 shows cerebellar atrophy in the patient.

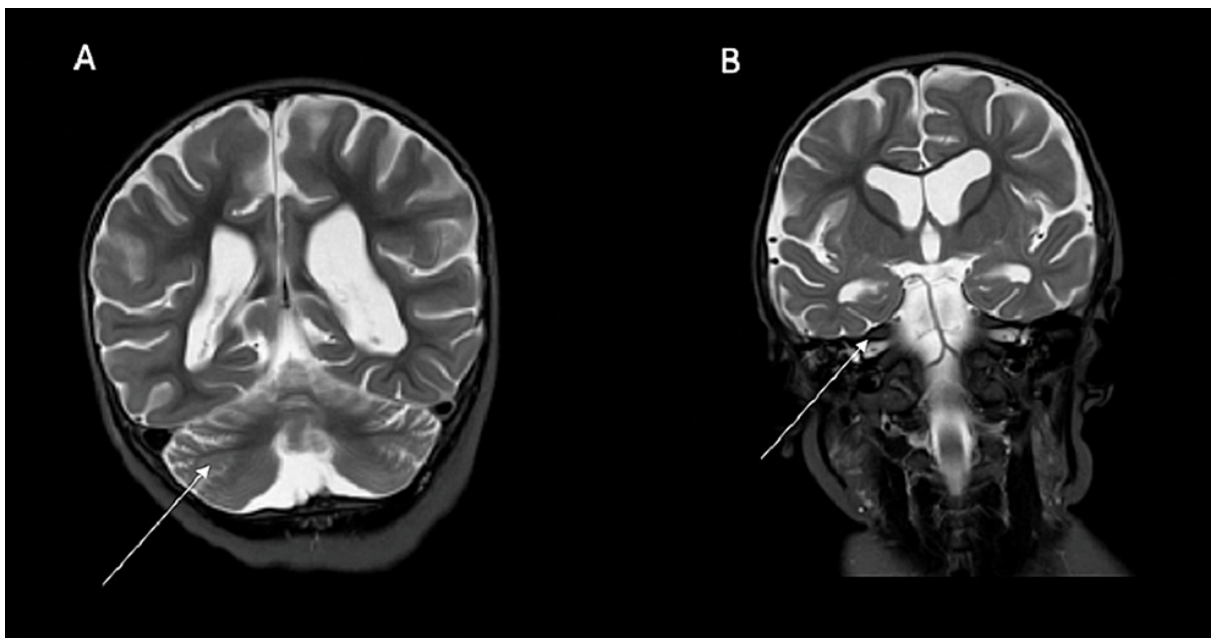

FIGURE 2: Panel A: T2 MRI sequence, coronal view; Panel B: T2 MRI sequence, coronal view

Both images show cerebellar atrophy (white arrows).

Electroencephalogram (EEG)

At times, there was high amplitude with irregular spikes and waves. Then, the spikes and waves were immediately followed by brief diffuse attenuation + - overlying fast activity, often without a clear clinical correlation but at times with an associated myoclonic jerk. At least eight of these seizures were noted within 24 hours. 


\section{Cureus}

Impression: The EEG was markedly abnormal when awake and asleep. There were abundant multi-focal and diffuse epileptiform discharges and multiple recorded seizures with multifocal onset. Findings were consistent with epileptic encephalopathy and a predominance of myoclonic or brief tonic seizures.

\section{Genetic testing}

The first mutation was already reported, and an additional test shows an additional deletion of unknown significance.

1) MYO5A, located at band 15q21, classical of GS.

2) Loss 18p11.32p11.31 (2.1 MB): Previously reported in a patient with refractory seizures and developmental delay [6].

Impression and treatment: The ketogenic diet was weaned due to the lack of efficacy. He was discharged with the following medications: lacosamide $40 \mathrm{mg}$ BID, clobazam $10 \mathrm{mg}$ TID, levetiracetam $500 \mathrm{mg}$ BID, cannabinol $500 \mathrm{mg}$, zonisamide $50 \mathrm{mg}$, and diazepam PRN.

The prognosis of the patient is mainly unknown due to the natural course of the disease. The patient also had an additional mutation [loss 18p11.32p11.31 (2.1 MB)], which could be worsening the condition.

\section{Discussion}

Chédiak-Higashi syndrome, Elejalde syndrome, Hermansky-Pudlak syndrome type 2, and GS share similar features. All the syndromes present with partial albinism. Neurological features can be seen in all the differentials, except GS3. Immunodeficiency is seen in all the disorders except in Elejalde syndrome and GS1.

Making the differential diagnosis of these three syndromes could be challenging. Table 2 showed the main differences among these three disorders $[4,7-9]$. 


\section{Cureus}

\begin{tabular}{|c|c|c|c|}
\hline Condition & Clinical Manifestations & Genetics & Epidemiology \\
\hline $\begin{array}{l}\text { Chédiak- } \\
\text { Higashi } \\
\text { syndrome } \\
{[8]}\end{array}$ & $\begin{array}{l}\text { Partial albinism. Retina pigmentation, impaired visual acuity, photophobia, } \\
\text { increase red reflex, nystagmus. Early-onset immunodeficiency. Mucosal bleeding, } \\
\text { easy bruising. Neurologic manifestations appeared in early adulthood. They } \\
\text { included: ataxia, tremors, motor, and sensory neuropathies, absent deep tendon } \\
\text { reflexes. Accelerated phase: fever, hepatosplenomegaly, lymphadenopathy, } \\
\text { neutropenia, anemia, thrombocytopenia, most patients die within the first ten } \\
\text { years of life. Patients have an increased risk of developing a stroke. }\end{array}$ & $\begin{array}{l}\text { Autosomal } \\
\text { recessive. } \\
\text { Lysosomal } \\
\text { trafficking } \\
\text { regulator is } \\
\text { located in } \\
\text { chromosome } 1 \\
\text { (1q2-q44). }\end{array}$ & $\begin{array}{l}\text { Unknown } \\
\text { exact } \\
\text { prevalence. } \\
\text { Fewer than } \\
500 \text { cases } \\
\text { worldwide. }\end{array}$ \\
\hline $\begin{array}{l}\text { Elejalde - } \\
\text { syndrome } \\
{[7]}\end{array}$ & $\begin{array}{l}\text { Partial albinism, not immunocompromised early-onset neurologic dysfunction: } \\
\text { marked hypotonia, hyporeflexia or hyperreflexia, spastic or flaccid hemiplegia or } \\
\text { quadriplegia, seizures, ataxia, developmental delay. Ophthalmologic } \\
\text { manifestations included: nystagmus, diplopia, pupilar areflexia, congenital } \\
\text { amaurosis. }\end{array}$ & $\begin{array}{l}\text { Autosomal } \\
\text { recessive. } \\
\text { MYO5A gene } \\
\text { mutations. }\end{array}$ & $\begin{array}{l}20 \text { cases } \\
\text { have been } \\
\text { reported up } \\
\text { to } 2019 .\end{array}$ \\
\hline $\begin{array}{l}\text { Hermansky- } \\
\text { Pudlak } \\
\text { syndrome } \\
\text { type } 2 \text { [9] }\end{array}$ & $\begin{array}{l}\text { Partial albinism, neutropenia, low platelet count, microcephaly, horizontal } \\
\text { nystagmus, mental retardation. }\end{array}$ & $\begin{array}{l}\text { Autosomal } \\
\text { recessive } \\
\text { disease. } \\
\text { Mutations in } \\
\text { AP3B1 gene on } \\
\text { chromosome } 5 . \\
\text { The protein } \\
\text { function is } \\
\text { lysosomal } \\
\text { trafficking. }\end{array}$ & Unknown \\
\hline $\begin{array}{l}\text { Griscelli } \\
\text { Type } 1[4]\end{array}$ & $\begin{array}{l}\text { Partial albinism, not immunocompromised, neurological deficits, severe } \\
\text { developmental delay, and mental retardation. }\end{array}$ & $\begin{array}{l}\text { Mutation in the } \\
\text { MYO5A gene on } \\
\text { chromosome } \\
15 q 21 .\end{array}$ & \multirow{3}{*}{$\begin{array}{l}\text { Only } 150 \\
\text { cases have } \\
\text { been } \\
\text { reported. }\end{array}$} \\
\hline $\begin{array}{l}\text { Griscelli } \\
\text { Type } 2[4]\end{array}$ & $\begin{array}{l}\text { Partial albinism, immunodeficiency, hemophagocytic syndrome. The } \\
\text { hemophagocytic syndrome cause infiltration in the organs, including the brain. }\end{array}$ & $\begin{array}{l}\text { Mutation in the } \\
\text { RAB27A gene on } \\
\text { chromosome } \\
15 q 21 .\end{array}$ & \\
\hline $\begin{array}{l}\text { Griscelli } \\
\text { Type } 3[4]\end{array}$ & $\begin{array}{l}\text { Partial albinism. without neurological or immunological compromise. Only minor } \\
\text { features are seen in GS3. }\end{array}$ & $\begin{array}{l}\text { Mutation in either } \\
\text { melanophilin or } \\
\text { MYO5A genes. }\end{array}$ & \\
\hline
\end{tabular}

\section{TABLE 2: Diffrential dianosis of Griscelli syndrome}

MYO5A: Myosin-Va; RAB27A: Ras-related protein Rab-27A

Additionally, we looked at other reported cases of GS and seizures in pediatric populations. We used an advanced PubMed strategy with the following terms: (Griscelli syndrome[Title/Abstract]) AND (seizures[Title/Abstract]). We found 12 cases with both features. Table 3 shows the reported GS cases, either type 1 or 2 , with seizures $[1,4,10-18]$.

\begin{tabular}{|c|c|c|c|c|}
\hline $\begin{array}{l}\text { Author, } \\
\text { year }\end{array}$ & $\begin{array}{l}\text { Type of } \\
\text { GS, age, } \\
\text { sex }\end{array}$ & Clinical Features & $\begin{array}{l}\text { 1) Age of onset, 2) treatment, 3) } \\
\text { Outcome. }\end{array}$ & MRI findings \\
\hline $\begin{array}{l}\text { Russ et al } \\
2019[11]\end{array}$ & $\begin{array}{l}\text { Griscelli } \\
\text { Type } 2 \text {, } \\
1 \text { year, } \\
\text { female. }\end{array}$ & $\begin{array}{l}\text { Status epilepticus, } \\
\text { encephalitis, } \\
\text { oculocutaneous albinism, } \\
\text { pancytopenia, } \\
\text { hypertriglyceridemia, } \\
\text { developed hemophagocytic } \\
\text { lymph histiocytosis at year } \\
\text { one. }\end{array}$ & $\begin{array}{l}\text { Three months. Status epilepticus related } \\
\text { to Influenza. She was treated with } \\
\text { levetiracetam, oxcarbazepine, and } \\
\text { fosphenytoin. A year later, she continued } \\
\text { to have refractory epilepsy. }\end{array}$ & $\begin{array}{l}\text { Hyperintensities of the corona } \\
\text { radiata and periventricular white } \\
\text { matter. }\end{array}$ \\
\hline
\end{tabular}




\section{Cureus}

Griscelli Developmental delay, silver-

Masri et al, type 2, 6 gray hair, bronze color skin, 2008 [1] years, generalized hypotonia, male anemia.

Griscelli Silvery-gray hair, spastic

Saini et al, type 2, 3 quadriparesis, hyperreflexia, 2014 [12] years, hepatosplenomegaly, male. abnormally pigmented skin.

Cagdas et al, 2012

[13]

Griscelli Silver-gray hair type 1,7 developmental months, delay, hypotonia, lack of male head control

Griscelli 2017 [14] 11 months,

Silver-grey hair, increased tone, pancytopenia male.
Sahu et al, type 2,

Six years old. No treatment discuss. Focal seizures related to a fever of unknown origin. Two weeks later, he develops generalized tonic-clonic seizures; The patient died because of rapid neurological deterioration.

Three years old. Not treatment discuss.

Focal seizures related to a viral process that caused an altered level of

consciousness.

Seven months. Currently, at age four, his seizures are well-controlled with carbamazepine and clonazepam. He was experiencing seizures for four months. EEG showed frequent sharp waves in the left hemisphere. Seizures were difficult to control.

Convulsion since he had 18 days of life. No treatment discussed. The patient died two months after the onset of symptoms

Six years old. No treatment discussed. He had seizures and subsequent stupor with tonic-clonic seizures. The patient died 12 days after admission, due to an accelerated phase of hemophagocytic syndrome.

One year old. She was treated with phenytoin, levetiracetam, valproate, midazolam infusion. Status epilepticus remained refractory until receiving ketamine. Left frontal seizures and status epilepticus. It was very difficult to stop the convulsions. She continued to have intractable seizures and died on day 14 of hospitalization.

Griscelli,

16

Alva- months,

Moncayo male,

et al, 2003 most

[16]

probably

Developmental delay, silvergrey hair, pancytopenia, and hepatosplenomegaly.

Griscelli

type 2

Anasarca, jaundice,

Griscelli, splenomegaly, silver-grey

6 years, hair, horizontal nystagmus,

Dinakar et female, retinal pigmentation,

al, 2003 most generalized hypertonia,

[17]
16 months of age. No treatment discussed. Generalized, tonic and refractory seizures that progressed to a vegetative state. probably

hyperreflexia, and

Griscelli pancytopenia. Her IQ is 67.

type 2 She also has a regression of milestones since age four.

Griscelli

type 1, 2 Silver-grey hair, hypotonia, years, developmental delay.
MRI showed white and grey matter involvement and periventricular hyperintensities.

Hyperintensities in the cerebellar hemisphere and splenium of the corpus callosum.

Normal MRI reported at 1.5 years.

Multiple hyperdense foci in the white matter of the left hemisphere; Cortical and subcortical hyperintense lesions on MRI.

There are frontal, cortical, and subcortical lesions; white matter lesions in the periventricular areas. Also, there is hyperintensity in the upper pons, quadrigeminal plate, upper pons, bilateral caudate, lentiform nucleus, and splenium of the corpus callosum.

On T2/Flair: No hyperintensities in the periventricular area, cerebellar hemispheres, and white matter.

MRI showed diffuse white matter demyelination, mainly in the bilateral frontotemporal area; a biopsy of the skin showed hyperpigmentation with accumulations of melanin.
Seizures started at age two. No treatment discussed.

Two years old. No treatment discussed.

Multiple seizures, despite multiple medications. The seizures remained difficult to manage.
CT scan showed a DandyWalker cyst. 


\section{Cureus}

Thomas et

al, 2009 [4]

\begin{tabular}{|c|c|c|}
\hline & $\begin{array}{l}\text { type } 1,2 \\
\text { months, } \\
\text { female }\end{array}$ & $\begin{array}{l}\text { Silver grey hair, hypotonia, } \\
\text { motor delay. }\end{array}$ \\
\hline $\begin{array}{l}\text { maksoud } \\
\text { al, } 2020 \\
\text { 8] }\end{array}$ & $\begin{array}{l}\text { Griscelli } \\
\text { type } 1,7 \\
\text { months, }\end{array}$ & $\begin{array}{l}\text { Silvery-grey hair and } \\
\text { eyebrows, developmental } \\
\text { delay, hypotonia. }\end{array}$ \\
\hline
\end{tabular}

Two months old. Treatment not discussed. EEG showed a hypsarrhythmia Information not available. pattern.

Seven months old. No treatment discussed. Seizures control with multiple Bilateral symmetrical widening of medications. The other sibling has GS1 the Sylvian fissure.

\section{TABLE 3: Reported cases of Griscelli syndrome with seizures}

On literature search, we found four cases of GS1 with seizures and eight cases of GS2 and seizures. Two out of four cases seem to have refractory epilepsy while the others only have mild epilepsy [4,18]. Interestingly, in one report, two siblings had the same mutation, and both were diagnosed with GS1, but just one sibling had epilepsy, showing that different phenotypes could be present with the same mutation [18]. Five out of eight cases of GS2 died shortly after developing seizures. One patient developed seizures and progressed to a vegetative state [16]. Another patient continued to have refractory epilepsy a year later; the first episode. There is no description of what medication was tried [11]. Our patient has refractory epilepsy, and he was treated with more medications than other previously described cases.

There have only been 20 cases reported of GS1 based on our literature review, so information is limited. The most common neurological manifestations are hypotonia, seizures, neurodevelopmental delay, and ophthalmological features [4]. In our case, the patient did not have ocular manifestations. Once the diagnosis of GS1 has been made, it is important to differentiate it from GS2, which can also cause neurological symptoms. Congenital cerebellar atrophy is the most common MRI sign in GS1 [10]. The main findings in our patient were cortical atrophy, cerebellar atrophy, and ex-vacuo ventriculomegaly.

The neurological features of GS1 are related to the gene MYO5A, which regulates the organelle transport in melanocytes and neuronal cells [5]. The abnormal movement of melanosomes altered intracellular vesicle transport, so fast axonal transport in nerve cells is reduced. Neuronal development, axonal transport, dendritic spine structure, and synaptic plasticity altered [19]. The neurological features of GS2 are related to the accelerated phase of HPS due to histiocytic infiltration in the central nervous system [10]. The gene regulates the docking of proteins and exocytosis of granules containing granzyme and perforins. The lack of granzymes and perforins explained the immunodeficiency in GS2 [4]. Neurological manifestations in GS2 can be a sign of an accelerated phase of HPS [10].

Microscopic examination of the hair shafts allows differentiating GS from similar disorders like ChediakHigashi and Elejaldes syndrome [1]. In GS, there are large clumps of melanin distributed irregularly. In Chediak-Higashi, there are small clumps of melanin regularly distributed, and in Elejaldes syndrome, the clumps of melanin are distributed very similarly to GS [1]. Overall the prognosis is poor, and the limited information about GS1 left physicians without many options. Currently, bone marrow transplantation seems to be the only definitive treatment for GS [15]. Cannabinol was the anti-seizure medication more effective in the patient. There are no studies about GS and cannabinol. However, in other epilepsy syndromes of childhood, such as Dravet's syndrome and Lennox Gastau, cannabinol reduced the frequency of seizures by $37.2 \%$ in Lennox Gastau and 38.9 in Dravet's syndrome [20].

Interestingly, our patient also had a deletion on 18p11.32p11.31. This finding is remarkable because there is a case report by Verroti et al. describing a case with a deletion in 18p11.32p11.31. This patient presented with similar clinical features as our patient, including drug-resistant atypical absence epilepsy and severe developmental delay [6]. One crucial gene found in this region is the TGIF-1, expressed very early in the nervous system. Mutation in the TGIF-1 has been related to severe mental retardation and holoprosencephaly [6]. While seizures are expected in GS1. The frequency and severity of the seizures in our patient are more severe than other cases of GS1 with seizures. We believe that mutation in the MYOV5A gene combined with the deletion 18p11.32p11.31 in our patient explained the severity of the case.

\section{Conclusions}

We found four cases of GS1 with seizures and eight cases with GS2 and seizures. The neurological manifestation is GS1 is related to the MYO5a while the GS2 neurological manifestations are indirectly related to the HPS when there is an accelerated phase. The differential diagnosis between Chédiak-Higashi syndrome, Elejalde syndrome, and GS could be challenging. The microscopic finding is the most accurate method to differentiate among these disorders. The prognosis of these patients is poor, the same as in our patient. The mutation in the MYO5A gene and the 18p11.32p11.31 deletion could explain the severity of the seizures in our case. This is the first report of GS1 with a deletion in 18p11.32p11.31. 


\section{Additional Information \\ Disclosures}

Human subjects: Consent was obtained or waived by all participants in this study. Conflicts of interest: In compliance with the ICMJE uniform disclosure form, all authors declare the following: Payment/services info: All authors have declared that no financial support was received from any organization for the submitted work. Financial relationships: All authors have declared that they have no financial relationships at present or within the previous three years with any organizations that might have an interest in the submitted work. Other relationships: All authors have declared that there are no other relationships or activities that could appear to have influenced the submitted work.

\section{References}

1. Masri A, Bakri FG, Al-Hussaini M, Al-Hadidy A, Hirzallah R, de Saint Basile G, Hamamy H: Griscelli syndrome type 2: a rare and lethal disorder. J Child Neurol. 2008, 23:964-7. 10.1177/0883073808315409

2. Alsugair F, Jadkareem D, Alhazmi R, Alhaidey A: Neuroimaging findings in Griscelli syndrome: A case report and review of the literature. Radiol Case Rep. 2020, 15:2339-42. 10.1016/j.radcr.2020.09.005

3. Mansouri Nejad SE, Yazdan Panah MJ, Tayyebi Meibodi N, Ashraf Zadeh F, Akhondian J, Beiraghi Toosi M, Eslamieh H: Griscelli syndrome: a case report. Iran J Child Neurol. 2014, 8:72-5.

4. Thomas ER, Walker LJ, Pullaperuma S, et al.: Griscelli syndrome type 1: a report of two cases and review of the literature. Clin Dysmorphol. 2009, 18:145-8. 10.1097/MCD.0b013e328317b870

5. Kharkar V, Pande S, Mahajan S, Dwiwedi R, Khopkar U: Griscelli syndrome: a new phenotype with circumscribed pigment loss?. Dermatol Online J. 2007, 13:17.

6. Verrotti A, Palka C, Prezioso G, Alfonsi M, Calabrese G, Palka G, Chiarelli F: Deletion 18p11.32p11.31 in a child with global developmental delay and atypical, drug-resistant absence seizures. Cytogenet Genome Res. 2015, 146:115-9. 10.1159/000438502

7. Cahali JB, Fernandez SA, Oliveira ZN, Machado MC, Valente NS, Sotto MN: Elejalde syndrome: report of a case and review of the literature. Pediatr Dermatol. 2004, 21:479-82. 10.1111/j.0736-8046.2004.21414.x

8. Ajitkumar A, Yarrarapu SNS, Ramphul K: Chediak Higashi Syndrome. StatPearls Publishing, Treasure Island (FL); 2021.

9. Alizadeh Z, Nabilou S, Mazinani M, et al.: Partial albinism and immunodeficiency in patients with Hermansky-Pudlak Type II: introducing 2 novel mutations. Scand J Immunol. 2021, 93:e12966. 10.1111/sji.12966

10. Ashrafi MR, Mohseni M, Yazdani S, et al.: Bilateral basal ganglia involvement in a patient with Griscelli syndrome. Eur J Paediatr Neurol. 2006, 10:207-9. 10.1016/j.ejpn.2006.07.005

11. Russ A, Mack J, Green-Murphy A, Occidental M, Mian A: Griscelli type 2 syndrome and hemophagocytic lymphohistiocytosis: sisters with the same mutation but different presentations. J Pediatr Hematol Oncol. 2019, 41:473-7. 10.1097/MPH.0000000000001522

12. Saini AG, Nagaraju S, Sahu JK, Rawat A, Vyas S, Singhi P: Teaching neuroImages: Griscelli syndrome and CNS lymphohistiocytosis. Neurology. 2014, 82:e122-3. 10.1212/WNL.0000000000000288

13. Cağdaş D, Ozgür TT, Asal GT, et al.: Griscelli syndrome types 1 and 3: analysis of four new cases and longterm evaluation of previously diagnosed patients. Eur J Pediatr. 2012, 171:1527-31. 10.1007/s00431-0121765-x

14. Sahu C, Netam SS, Bhutada BR, Jaiswal SJ: Griscelli syndrome: a rare disorder. Neurol India. 2017, 65:86970. 10.4103/neuroindia.NI 76216

15. Panigrahi I, Suthar R, Rawat A, Behera B: Seizure as the presenting manifestation in Griscelli syndrome type 2. Pediatr Neurol. 2015, 52:535-8. 10.1016/j.pediatrneurol.2015.01.010

16. Alva-Moncayo E, Castro-Tarín M, Pérez-Casillas R: Griscelli syndrome in México. Description of a case with neurological manifestations [Article in Spanish]. Rev Neurol. 2003, 36:347-50. 10.33588/rn.3604.2002451

17. Dinakar C, Lewin S, Kumar KR, Harshad SR: Partial albinism, immunodeficiency, hypergammaglobulinemia and Dandy-Walker cyst--a Griscelli syndrome variant. Indian Pediatr. 2003, 40:1005-8.

18. Abd Elmaksoud MS, Gomaa NS, Azouz HG, et al.: Genetic analysis in three Egyptian patients with Griscelli syndrome Type 1 reveals new nonsense mutations in MYO5A. Clin Exp Dermatol. 2020, 45:789-92. $10.1111 /$ ced.14220

19. Van Gele M, Dynoodt P, Lambert J: Griscelli syndrome: a model system to study vesicular trafficking . Pigment Cell Melanoma Res. 2009, 22:268-82. 10.1111/j.1755-148X.2009.00558.x

20. von Wrede R, Helmstaedter C, Surges R: Cannabidiol in the treatment of epilepsy. Clin Drug Investig. 2021, 41:211-20. 10.1007/s40261-021-01003-y 